\title{
THE INFLUENCE OF SOCIAL MEDIA ACCESS ON SELF-PERCEPTION OF ORAL HEALTH-RELATED QUALITY OF LIFE CONSIDERING THE MALOCCLUSION AMONG ADOLESCENTS FROM AMAZON REGION
}

\author{
Cibelle Santos (1D $ه$
}

Universidade Federal do Pará I Belém - PA - Brasil

Fausto Mendes (D)

Universidade de São Paulo I São Paulo - SP - Brasil

David Normando (ID $\triangle$

Universidade Federal do Pará I Belém - PA - Brasil 


\section{ABSTRACT}

This cross-sectional study evaluated the influence of social media access on self-perception of oral health-related quality of life (OHRQoL) considering the malocclusion among low-income adolescents from riverine and urban communities in the Amazon. 266 adolescents without access to social media, answered the Child Perceptions Questionnaire (CPQ 11-14) and were clinically evaluated to determine their malocclusion using the Dental Aesthetic Index (DAI). A multilevel Poisson regression analysis evaluated the association between variables related to the individuals $\left(1^{\text {st }}\right.$ level) and regions $\left(2^{\text {nd }}\right.$ level) and quality of life. DAI and CPQ mean values were, respectively, 29.6 (SD 6.8) and 8.3 (SD 6.9) for the adolescents from the riverine community farthest from the urban center, 24.5 (SD 6) and 11.8 (SD 7.9) for those living in the riverine area nearest to the urban center and 23.8 (SD 5.9) and 11.4 (SD 6.8) for urban adolescents. The severity of malocclusion had no statistically significant impact on self-perception of OHRQoL (RR 1.00 to 1.05). Adolescents in the remote areas reported a better quality of life $(\mathrm{RR}=0.38$, $95 \% \mathrm{CI}=0.24-0.60, \mathrm{p}<0.001)$, regardless the severity of dental malocclusion., than those in the urban area.

Keywords: dental malocclusion; quality of life; adolescent.

\section{A INFLUÊNCIA DO ACESSO ÀS MÍDIAS SOCIAIS NA AUTOPERCEPÇÃO DA RELAÇÃO DA SAÚDE BUCAL COM A QUALIDADE DE VIDA CONSIDERANDO A MÁ OCLUSÃO EM ADOLESCENTES DA REGIÃO AMAZÔNICA} RESUMO

Este estudo transversal avaliou a influência do acesso às mídias sociais na autopercepção da qualidade de vida relacionada à saúde bucal (QVrSB), considerando a má oclusão entre adolescentes de baixa renda das áreas ribeirinhas e urbanas da Amazônia. 266 adolescentes sem acesso às mídias sociais responderam ao questionário de percepção infantil (CPQ 11-14) e foram avaliados clinicamente para determinar sua má oclusão através do Índice de Estética Dental(DAI). A análise multinível da regressão de Poisson avaliou a associação entre variáveis relacionadas aos indivíduos ( $1^{\circ}$ nível) e regiões ( $2^{\circ}$ nível) e qualidade de vida. Os valores médios do DAI e CPQ foram, respectivamente, 29,6 (DP 6,8) e 8,3 (DP 6,9) para os adolescentes da comunidade ribeirinha mais distante do centro urbano; 24,5 (DP 6) e 11,8 (DP 7,9) para os residentes da área ribeirinha mais próxima do centro urbano; e 23,8 (DP 5,9) e 11,4 (DP 6,8) para adolescentes urbanos. A severidade da má oclusão não teve impacto significativo na autopercepção da QVrSB (RR 1,00 a 1,05). Adolescentes de áreas remotas relataram melhor qualidade de vida $(R R=0,38$, IC 95\% = 0,24-0,60, $p<0,001)$, independente da severidade da má oclusão, do que aqueles que vivem na área urbana.

Palavras-chave: má oclusão; qualidade de vida; adolescentes.

\section{INFLUENCIA DEL ACCESO A LAS REDES SOCIALES EN LA AUTOPERCEPCIÓN DE LA RELACIÓN ENTRE SALUD BUCAL Y CALIDAD DE VIDA CONSIDERANDO LA MALOCLUSIÓN EN ADOLESCENTES DE LA REGIÓN AMAZÓNICA}

Este estudio transversal evaluó la influencia del acceso a las redes sociales en la autopercepción de la calidad de vida relacionada con la salud bucal (QVrSB), considerando la maloclusión en adolescentes de escasos recursos de las zonas ribereñas y urbanas de la Amazonía. 266 adolescentes sin acceso a redes sociales respondieron el cuestionario de percepción infantil (CPQ 11-14) y fueron evaluados clínicamente para determinar su maloclusión y Índice de Estética Dental (DAI). El análisis multinivel de regresión de Poisson evaluó la asociación entre las variables relacionadas a los individuos, las regiones y la calidad de vida. Los valores medios de DAI y CPQ fueron respectivamente, 29.6 (SD 6.8) y 8.3 (SD 6.9) para los adolescentes de la comunidad ribereña más alejada del centro urbano, 24.5 (SD 6) y 11.8 (SD 7.9) para residentes del área ribereña más cercana, 23.8 (SD 5.9) y 11.4 (SD 6.8) para adolescentes urbanos. La gravedad de la maloclusión no tuvo un impacto significativo en la CVRS (RR 1,00 a 1,05). Los adolescentes de áreas remotas reportaron una mejor calidad de vida $(\mathrm{RR}=0.38$, IC 95\% $=$ 0.24-0.60, $\mathrm{p}<0.001$ ), independientemente de la severidad de la maloclusión, que aquellos que viven en el área urbana.

Palabras clave: maloclusión dental; calidad de vida; adolescente. 


\section{INTRODUCTION}

The Amazon region has diverse populations among its extensive geographical areas, each one with its own characteristics. Riverine populations are characterised by inhabiting the banks of the rivers and depending on the cycles of nature-mainly the phenomena of flood and ebb of the rivers-to establish their economic and cultural relations. These characteristics depict a typically isolated daily life, with family routines confined mostly to one's own residence. Survival depends on fishing and subsistence farming (S. Silva et al. 2010). The difficulty of accessing basic sanitation and health services, television and the internet might influence the perception of quality of life (CohenCarneiro et al. 2009, 2010).

Malocclusion consist in a deviation in the process of maxillary growth and the positioning of the teeth (Moyers 2014) that can result in physical, psychological, and social consequences. Several current clinical studies aimed to evaluate patients' oral health-related quality of life (OHRQoL) associated with the evaluation of oral health care and the presence of malocclusion and its implications on physical, social, and emotional wellbeing(Sun et al. 2017a). According to a systematic review, orthodontic treatment during childhood or adolescence leads to moderate improvement in the emotional and social well-being dimensions of oral health related quality of life, although the evidence is of low and moderate quality (Javid et al. 2017). In addition, the presence of malocclusion seems to interfere negatively with the development of affective relationships among young adults, and the facial aesthetic is important for social life and securing employment (Henson et al. 2011; Pithon et al. 2014).

While most studies show that malocclusion negatively influences the quality of life (Kavaliauskienè et al. 2018; Bittencourt et al. 2017; Sun et al. 2017b; Piassi et al. 2019; Kunz et al. 2019), a report conducted in Masshad (Iran) high scholls examinned 120 male students and had not found correlation between emotional well-being, social well-being, and malocclusions. Also, the patients with the most severe forms of malocclusion did not experience the lowest level of life quality (Heravi et al. 2011), probably influenced by the socioeconomic and cultural conditions (L. Silva et al. 2016). Cultural, socioeconomic, religious, and geographical conditions can modulate perceptions on the quality of life in different communities (Cohen-Carneiro et al. 2009, 2010). The impact of factors that influence the quality of life of riverines may suggest prospects for remote communities living in other isolated regions around the world and may influence the decision on the necessity of orthodontic treatment. The more perceived is the malocclusion as a controlling determinant for quality of life, the greater the importance of the treatment.

The objective of this study was to evaluate the influence of social media access 
on self-perception of oral health-related quality of life (OHRQoL) considering the malocclusion from typically semi-isolated Amazonian riverine and urban communities. Due to the eminently aesthetic character of malocclusion and the possible influence of the social media access on self-perception of quality of life, the null hypothesis considers that the absence of the social media access can influence the self-perception of oral health-related quality of life considering the malocclusion, reported by adolescents from remote communities.

\section{METHODS}

This cross-sectional study was reported following the STROBE guideline and was carried out in public schools of two riverine and one urban communities in the municipality of Abaetetuba, Pará, Brazil. The Research Ethics Committee of the Health Sciences Institute of Federal University of Pará approved this study under protocol no. 055.941. Prior to the examination, an informed consent was sent for the adolescents and his parents. The period of recruitment and data collection occurred from September 2018 to June 2019.

The chosen municipal area is located on the banks of the river Maratauíra, a tributary of the Tocantins River, in the Amazon region. It has approximately 45 islands forming the "Islands Region"; the riverine population lives in this area (Figure 1). According to the 2010 Demographic Census conducted by the Brazilian Institute of Geography and Statistics (IBGE 2016), the municipality has an estimated population of approximately 157,698 inhabitants. The region's Poverty Index is $51.37 \%$. Regarding education, the municipality
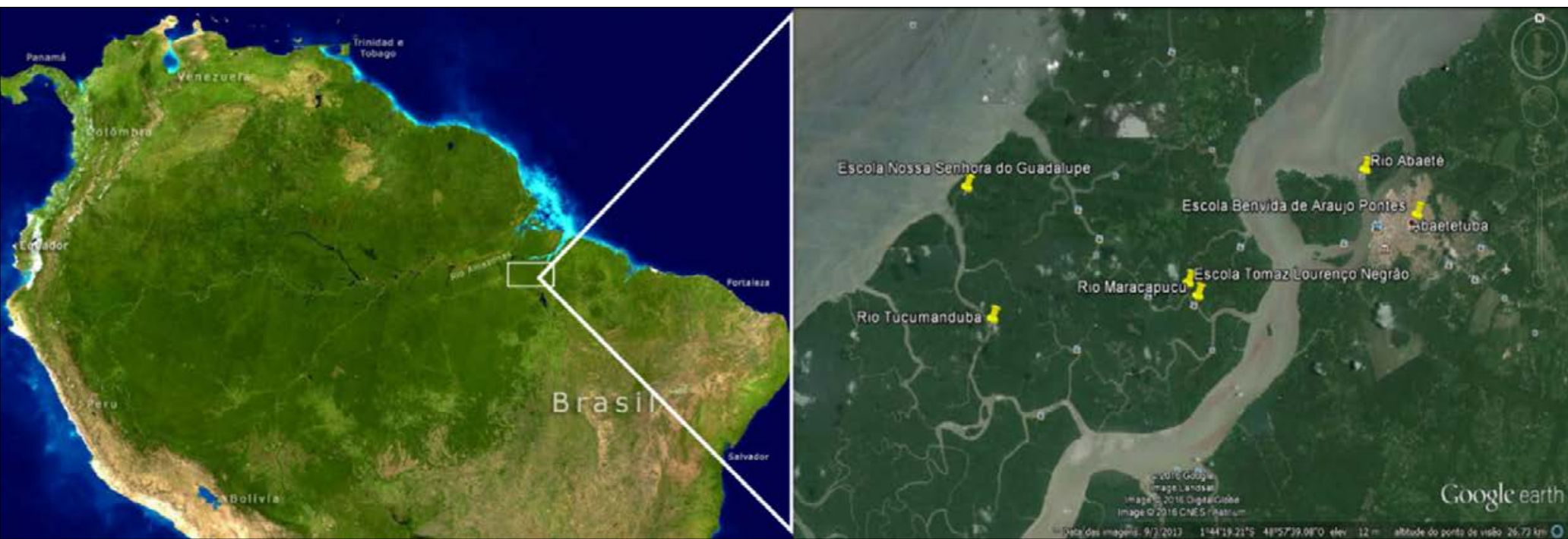

Figure 1 - Map pf the Amazon region showing the locations of the schools included in the study. 
has 181 elementary schools, 160 of which are public schools, and 18 secondary schools, 14 of which are public.

The participants were selected from two riverine schools of different distances from urban center, and two other schools located in a typical Amazonian urban to represent the urban population. The Benvinda de Araujo Pontes and São Francisco Xavier schools are in the urban area of Abaetetuba, Pará. In the Maracapucu River region, the Tomaz Antônio Negrão school, located $8.8 \mathrm{~km}$ from an urban center, was evaluated. In the Tucumanduba River region, the Nossa Senhora do Guadalupe school, located about $27.3 \mathrm{~km}$ away from an urban center, was evaluated (Figure 1).

The schools belonged to the public-school system and were selected for convenience: they are in the Islands Region and the urban area of the municipality of Abaetetuba, Pará, Amazon region, Brazil. Due to the geographic and social isolation, the sample was obtained through a census. All adolescents that were present at their respective school in the period of the exam were invited and agreed to participate of the study (Table 1). There is no ethical variation in the sample. In general, students from public school are classified as low-income (Colussi et al. 2017) and report a greater impact on oral health-related quality of life (Machry et al. 2018).

The department of municipal education authorized the research. It was requested permission from each school coordination for research application and was conceived. Data collection was performed in a break between classes in a non-detrimental way of school activities. A printed version of the $\mathrm{CPQ}$ questionnaire was given to each adolescent. A dentist assisted the scholars to complete the CPQ questionnaire. Supervised brushing activities, distribution of oral hygiene kits and educational lectures regarding oral health were carried out in schools.

The clinical evaluation of malocclusion was performed using the DAI Index (Dental Aesthetics Index) advocated by the World Health Organization (WHO 2013) as an epidemiological instrument for oral health in epidemiological evaluations, the DAI index is used to classify dental aesthetics and the need for treatment based on a socially acceptable dental appearance (Garbin et al. 2010; Guimarães et al. 2018). The clinical evaluation was conducted by a single examiner in accordance with the guide for epidemiological surveys in oral health of the WHO, previously calibrated. Quantification of malocclusion was classified according to the DAI as follows:

DAI $\leq$ 25: no abnormality or mild malocclusion, little or no need for orthodontic treatment.

DAI = 26-30: defined malocclusion, treatment is considered elective.

DAI = 31-35: severe malocclusion, treatment is considered highly desirable.

DAI $\geq 35$ : very severe or incapacitating malocclusion, treatment is considered essential. 
The self-perception of oral health-related quality of life was evaluated by the Brazilian version of the CPQ 11-14 (Child Perception Questionnaire), which was developed specifically to evaluate the perception of children and adolescents about how oral health conditions have physical and psychological impacts (Foster Page et al. 2005).Individuals were advised about how to complete the questionnaire and instructed to mark only one response per item. The questionnaire was composed of 25 items distributed into four domains: oral symptoms, functional limitations, emotional and social well-being. The questions addressed the occurrence of certain events within the last three months. The following scoring scale was used: never $=0$, once/twice $=1$, sometimes $=2$, often $=3$, every day/almost every day $=4$. Results were obtained by totaling all the scores that could range from 0 (no impact on the quality of life) to 100 (maximum impact on the quality of life).

A pilot study was performed to calibrate the evaluator for the clinical examination of malocclusion through the DAI index and evaluate method error. Thirty-two schoolchildren from an urban area of Abaetetuba, Pará, were re-examined. For the analysis of the casual and systematic error, the Bland-Altman method was used.

A multilevel Poisson regression analysis was performed to evaluate the association between explanatory variables related to the individual in the first level, sex andDAI (categorized according the severity of malocclusion); and regions (urban and riverine) in the second level, considering the distance from the school to urban center. The predictor variable was the total score of CPQ. The rationale of rates and respective $95 \%$ confidence intervals were calculated with this approach using the Stata 12.0 program (College Station, Texas, USA). The level of significance adopted $(\alpha)$ was equal to 0.05 .

\section{RESULTS}

In the urban area of the Abaetetuba municipality (Figure 1), 108 students were evaluated, 60 female and 48 males. Regarding the riverine area, in the Maracapucu River region, $8.8 \mathrm{~km}$ distance from the urban, 105 students were evaluated, 52 female and 53 males. In the region of the Rio Tucumanduba, the farthest community, 53 students were evaluated, 29 female and 24 males (Table 1). All parents agreed to the participation of their children.

The analysis of the severity of malocclusion and quality of life demonstrated the DAI and CPQ means respectively of 29.6 (Standard Deviation $-\mathrm{SD}=6.8)$ and $8.3(\mathrm{SD} 6.9)$ to the adolescents in the region of the Tucumanduba River, the most distance from the urban center. The urban adolescents presented the values of 23.8 (SD 5.9) and 11.4 (SD 6.8), and to the riverine area closest to the urban center (Maracapucu river) the values were 24.5 (SD 6.0) and 11.8 
(SD 7.9), which corresponds to mild or absent malocclusion (Table 2).

Univariate statistics showed that sex had no significant impact on the quality of life of adolescents $(\mathrm{RR}=0.99,95 \% \mathrm{CI}=0.92$ to 1.07 , $\mathrm{p}=0.83)$. Malocclusion was not a statistically significant factor impacting the self-perception of oral health-related quality of life, regardless of its magnitude (Table 3). Considering individuals with defined malocclusion $(\mathrm{DAI}=$ $26-30$ ), the rate ratio was $1.04,95 \% \mathrm{CI}=0.95$ $1.15, \mathrm{p}=0.394 ;$ severe malocclusion $(\mathrm{DAI}=$ 31-35) showed $\mathrm{RR}=1.04,95 \% \mathrm{CI}=0.91-1.18$, living in urban centers, belonging to

Table 1. Sample populations: Number of students and relative frequency by sex and location.

\begin{tabular}{|c|c|c|c|c|c|c|c|c|}
\hline & \multicolumn{2}{|c|}{ Urban school } & \multicolumn{2}{c|}{ Tucumanduba school } & Maracapucu school & \multicolumn{2}{c|}{ Total } \\
\hline & Male & Female & Male & Female & Male & Female & Male & Female \\
\hline $\mathrm{N}$ & 48 & 60 & 24 & 29 & 53 & 52 & 125 & 141 \\
\hline$\%$ & 44.4 & 55.5 & 45.2 & 54.7 & 50.4 & 49.5 & 46.9 & 53 \\
\hline Total & \multicolumn{3}{|c|}{108} & 53 & & & & \\
\hline
\end{tabular}

Table 2. Descriptive statistics for age, DAI and CPQ by sex and location.

\begin{tabular}{|c|c|c|c|c|c|c|c|c|c|}
\hline \multirow{3}{*}{ Variables } & \multicolumn{9}{|c|}{ Localities } \\
\hline & \multicolumn{3}{|c|}{ Urban } & \multicolumn{3}{|c|}{$\begin{array}{c}\text { Tucumanduba River } \\
\text { (27.3 km to urban center) }\end{array}$} & \multicolumn{3}{|c|}{$\begin{array}{c}\text { Maracapucu River } \\
\text { (8.8 km to urban center) }\end{array}$} \\
\hline & \multicolumn{3}{|c|}{ Mean (SD) } & \multicolumn{3}{|c|}{ Mean (SD) } & \multicolumn{3}{|c|}{ Mean (SD) } \\
\hline Sex & Male & Female & Total & Male & Female & Total & Male & Female & Total \\
\hline Age & $13.4(0.7)$ & $13.2(0.7)$ & $13.3(0.7)$ & $12.2(1.1)$ & $11.9(0.8)$ & $12.1(1)$ & $11.8(1)$ & $12.2(1.2)$ & $12(1.1)$ \\
\hline DAI & $24.1(5.2)$ & $23.5(6.4)$ & $23.8(5.9)$ & $25.4(6.4)$ & $23.6(5.4)$ & $24.5(6)$ & $29.6(6.8)$ & $30(11)$ & $29.8(9.2)$ \\
\hline CPQ & $12(7.4)$ & $10.9(6.2)$ & $11.4(6.8)$ & $11.7(8.3)$ & $11.9(7.6)$ & $11.8(7.9)$ & $7.2(6.7)$ & $9.3(7)$ & $8.3(6.9)$ \\
\hline
\end{tabular}


Table 3. Association of explanatory variables with the total scores obtained with the Child Perceptions Questionnaire (CPQ 11-14) at the clinical examination.

\begin{tabular}{|c|c|c|c|c|}
\hline $\begin{array}{l}\text { Explanatory } \\
\text { variables }\end{array}$ & $\begin{array}{l}\text { Ratio of unadjusted } \\
\text { rates }(95 \% \text { IC) }\end{array}$ & P-value & $\begin{array}{l}\text { Ratio of adjusted } \\
\text { rates ( } 95 \% \text { IC) }\end{array}$ & P-value \\
\hline \multicolumn{5}{|c|}{ First level: Adolescents $(n=266)$} \\
\hline \multicolumn{5}{|l|}{ Sex } \\
\hline Female & 1.00 & & * & \\
\hline Male & $0.99(0.92-1.07)$ & 0.832 & & \\
\hline DAI & $\leq 25$ & 1.00 & & 1.00 \\
\hline $26-30$ & $1.05(0.96-1.16)$ & 0.288 & $1.04(0.95-1.15)$ & 0.394 \\
\hline $31-35$ & $1.02(0.90-1.16)$ & 0.722 & $1.04(0.91-1.18)$ & 0.599 \\
\hline$\geq 36$ & $1.01(0.88-1.15)$ & 0.927 & $1.00(0.88-1.14)$ & 0.968 \\
\hline \multicolumn{5}{|c|}{ Second level: School (n = 266 adolescents) } \\
\hline \multicolumn{5}{|l|}{ School } \\
\hline Urban & 1.00 & & 1.00 & \\
\hline Riverine & $0.38(0.24-0.60)$ & $<0.001$ & $0.39(0.24-0.62)$ & $<0.001$ \\
\hline \multicolumn{5}{|c|}{ * Variables not included in the adjusted model } \\
\hline
\end{tabular}

different social classes, with some type of access to health services and the influence of social media, internet and television (Dimberg et al. 2015). Among adolescents from a town in the southeast of Brazil, malocclusion in the previous segment was significantly associated with a negative impact on oral health and the quality of life (Guimarães et al. 2018). Although there is a strong clinical evidence that malocclusion affects the oral health-related quality of life (Dalaie et al. 2018) our findings did not show a significant impact on the self-perception of oral health-related quality of life, regardless of its magnitude. Furthermore, adolescents living in remote riverine communities without access to social media reported a better quality of life than those living in urban communities (Table 3), which does not appear to be associated with malocclusion.

A study carried out in a riverine population of the Amazon, aged 15 to 25 years, revealed a significant impact of caries and periodontal 
disease on the self-perception of quality of life, probably related to the absence of health care within the community, the distance from these communities to the city, limitations in transportation systems and consequent prolongation of episodes of pain experienced (Maia et al. 2018). In opposite way, our study investigated the influence of social media access on the self-perception of oral health-related quality of life considering the malocclusion, which has an essentially aesthetic implication, in a riverine population of adolescents from 11 to 14 years. Different age groups may have different perceptions about the impact of oral health on quality of life. Moreover, the presence of other variables, including other oral diseases such as dental caries, periodontal diseases and psychosocial issues may mask the isolated influence of malocclusion on quality of life when evaluated by the dental aesthetics index (DAI) and consequently, the values of CPQ scores in this study.

Even though malocclusion seems to affect children's emotional and social well-being, dental caries is still the oral condition most associated with all aspects of OHRQoL in Brazilian 8-to-10-year-old children (Martins et al. 2018). Despite the global decline of caries disease, there are still inequalities related to oral health, especially in areas of lower socioeconomic conditions (Ravaghi et al. 2019; Mohamed \& Vettore 2019; Chaffee et al. 2017). Socioeconomic factors, especially in communities that coexist with poverty, as the riverine communities in the Amazon, make access to dental treatment difficult. The literature demonstrates an association between between malocclusion and economically underprivileged socioeconomic status (Sfreddo et al. 2019), which may be explained by the difficulty in gaining access to orthodontic treatment and its high cost. Adolescents from disadvantaged families, despite their poor oral health, tend to be less aware of their oral problems and are less likely to perceive their oral condition as an issue for their OHRQoL (Mohamed \& Vettore 2019), confirmed by the highest values of DAI to $29.6(\mathrm{SD}=6.8)$ and the lowest value of $\mathrm{CPQ}$ to $8.3(\mathrm{SD}=$ 6.9) related to adolescents in the region of Tucumanduba river, the most distance from the urban center. This seems to justify the fact that riverine population evaluated by this study reported a better quality of life than the urban communities.

Regarding sex, published research (Ashari \& Mohamed 2016) has shown that women are more concerned with aesthetics and are 
more critical and sensitive to the effects of malocclusion; thus, they are more likely to have oral health impact their quality of life. However, in this study, there was no statistical difference between the sexes for this age group of 11 to 14 years regarding the self-perception of oral health-related quality of life considering the malocclusion.

Most riverine communities, likely due to isolation and social exclusion, have little social organisation and political influence. The importance of evaluating health and disease perception favours the collection of data for health promotion, better allocation of public resources, and determination of the need for treatment. Due to the prevalence of malocclusion, the Ministry of Health of Brazil started to finance in 2010 orthodontics procedures for adolescents. However, the riverine communities do not have access to this service. There is a need to be included in public health policies, considering their peculiar characteristics related to the geographic reality of isolation (Cohen-Carneiro et al. 2009, 2010). When questioned during the clinical examination, most riverine adolescents reported that they had never visited a dentist. Although Brazil's national health policy advocates universality of access as a principle of the Brazilin Unified Health System, access to oral health services is still limited, as evidenced by striking regional inequalities.

The impact on quality of life may be associated with other variables not investigated by this study, such as schooling level and presence of dental caries. It is important to note that the CPQ questionnaire was not specifically developed to evaluate the impact of malocclusion on quality of life. However, it evaluates the self-perception of adolescents about the aesthetic and functional characteristics of the occlusion, and its psychological and social implications, generating relevant information to our investigation. Thereby, it does not invalidate the findings of this study, also considering we measure the self-perception of oralhealth-related quality of life considering the malocclusion through a statistical regression model.

The cultural habits and socioeconomic factors may influence the perception of quality of life, since the remote communities reported better quality of life. It is plausible that similar findings may be found in other remote communities living in isolation, with unfavorable socioeconomic conditions and the absence of the influence of social media. 


\section{CONCLUSION}

No significant impact of malocclusion on self-perception of oral health-related quality of life of adolescents in urban and riverine areas of the Amazon population examined was observed.
The absence of social media access can be associated to a better self-perception on the oral health-related quality of life of adolescents living in remote communities of the Amazon region.

\section{REFERENCES}

Ashari, A., e A. M. Mohamed. 2016. Relationship of the dental aesthetic index to the oral healthrelated quality of life. The Angle Orthodontist 86(2):337-342. DOI: https://doi.org/10.2319/121014-896.1

Bittencourt, J. M., L. P. Martins, C. B. Bendo, M. P. Vale, e S. M. Paiva. 2017. Negative effect of malocclusion on the emotional and social well-being of Brazillian adolescents: a population-based study. European fournal of Orthodontics 39(6):628-633. DOI: https://doi.org/10.1093/ejo/cjx020

Chaffee, B. W., P. H. Rodrigues, P. F. Kramer, M. R. Vítolo, e C. A. Feldens. 2017. Oral health-related quality-of-life scores differ by socioeconomic status and caries experience. Community Dentistry and Oral Epidemiology 45(3):216-224. DOI: https://doi.org/10.1111/cdoe.12279

Cohen-Carneiro, F., R. Souza-Santos, D. G. Pontes, A. V. Salino, e M. A. B. Rebelo. 2009. Oferta e utilização de serviços de saúde bucal no Amazonas, Brasil: estudo de caso em população ribeirinha do Município de Coari. Cadernos de Saúde Pública 25(8):1827-1838. DOI: https://doi.org/10.1590/S0102-311X2009000800019

Cohen-Carneiro,F., M. A.B.Rebelo, R.Souza-Santos, G.M. B. Ambrosano, A.V.Salino, eD. G.Pontes. 2010.Psychometric properties of the OHIP-14 and prevalence and severity of oral health impacts in a rural riverine population in Amazonas State, Brazil. Cadernos de Saúde Pública 26(6):1122-1130. DOI: https://doi.org/10.1590/S0102-311X2010000600006

Colussi, P. R., F. N. Hugo, F. W. Muniz, e C. K. Rösing. 2017. Oral health-related quality of life and associated factors in Brazilian adolescents. Brazilian Dental fournal 28(1):113-120. DOI: https://doi.org/10.1590/0103-6440201701098 
Dalaie, K., M. Behnaz, Z. Khodabakhshi, e S. Hosseinpour. 2018. Impact of malocclusion severity on oral health-related quality of life in an Iranian young adult population. European fournal of Orthodontics 12(1):129-135. DOI: https://doi.org/10.4103/ejd.ejd_61_17

Dimberg, L., K. Arnrup, e L. Bondemark. 2015. The impact of malocclusion on the quality of life among children and adolescents: A systematic review of quantitative studies. European fournal of Orthodontics 37(3):238-247. DOI: https://doi.org/10.1093/ejo/cju046

Foster Page, L. A., W.M. Thomson, A. Jokovic, eD. Locker. 2005. Validation of the Child Perceptions Questionnaire (CPQ 11-14). Journal of Dental Research 84(7):649-652. DOI: https://doi.org/10.1177/154405910508400713

Garbin, A. J. I., P. C. P. Perin, C. A. S. Garbin, e L. F. Lolli. 2010. Prevalência de oclusopatias e comparação entre a Classificação de Angle e o Índice de Estética Dentária em escolares do interior do estado de São Paulo-Brasil. Dental Press fournal of Orthodontics 15(4):94-102. DOI: https://doi.org/10.1590/S2176-94512010000400014

Guimarães, S. P. A., K. O. Jorge, M. J. F. Fontes, M. A. Ramos-Jorge et al. 2018. Impact of malocclusion on oral health-related quality of life among schoolchildren. Brazilian Oral Research 32: e95. DOI: https://doi.org/10.1590/1807-3107bor-2018.vol32.0095

Henson, S. T., S. J. Lindauer, W. G. Gardner, B. Shroff, E. Tufeksi, e A. M. Best, 2011. Influence of dental esthetics on social perceptions of adolescents judged by peers. American fournal of Orthodontics and Dentofacial Orthopedics 140(3):389-395. DOI: https://doi.org/10.1016/j.ajodo.2010.07.026

Heravi, F., F. Farzanegan, M. Tabatabaeec, e M. Sadeghi. 2011. Do malocclusions affect the oral healthrelated quality of life? Oral Health \& Preventive Dentistry 9(3):229-233.

Instituto Brasileiro de Geografia e Estatística (IBGE). 2016. Research Directorate. Coordination of population and social indicators. Available from: http://www.ibge.gov.br/home/estatistica/populacao/ estimativa2016. Accessed on February 14, 2019. 
Javid, H., M. Vettore, e P. E. Benson. 2017. Does orthodontic treatment before the age of 18 years improve oral health-related quality of life? A systematic review and meta-analysis. American fournal of Orthodontics and Dentofacial Orthopedics 151(4):644-655. DOI: https://doi.org/10.1016/j.ajodo.2016.12.011

Kavaliauskienè, A., A. Šidlauskas, e A. Zaborskis. 2018. Relationship between orthodontic treatment need and oral health-related quality of life among 11-18-Year-Old Adolescents in Lithuania. International fournal of Environmental Research and Public Health 15(5):1012. DOI: https://doi.org/10.3390/ijerph15051012

Kunz, F., P. Platte, S. Keß, L. Geim, F. Zeman, P. Proof, U. Hirschfelder, e A. Stellzig-Eisenhauer. 2019. Impact of specific orthodontic parameters on the oral health-related quality of life in children and adolescents: A prospective interdisciplinary, multicentre, cohort study. Journal of Orofacial Orthopedics 80(4):174-183. DOI: https://doi.org/10.1007/s00056-019-00181-x

Machry, R. V., J. K. Knort, F. Tomazoni, e T. M. Ardenghi. 2018. School environmental and individual factors influence oral health-related quality of life in Brazilian children. Brazilian Oral Research 32: e63. DOI: https://doi.org/10.1590/1807-3107bor-2018.vol32.0063

Maia, C. D. V. R., F. M. Mendes, e D. Normando. 2018. The impact of urban and riverine populations of the Amazon: A multilevel analysis. Plos One 13(11):1-11.

Martins, M. T., F. Sandenberg, C. B. Bendo, M. P. Vale, S. M. Paiva, e I. A. Pordeus, 2018. Dental caries are more likely to impact on children's quality of life than malocclusion or traumatic dental injuries. European fournal of Paediatric Dentistry 19(3):194-198. DOI: https://doi.org/10.23804/ejpd.2018.19.03.5

Mohamed, S., e M. V. Vettore. 2019. Oral clinical status and oral health-related quality of life: Is socioeconomic position a mediator or a moderator? International Dental fournal 69(2):119-129. DOI: https://doi.org/10.1111/idj.12420

Moyers, R. E. 2014. Ortodontia. Rio de Janeiro: Guanabara Koogan. 
Piassi, E., L. S, Antunes, T. C. A Graça, e L. A. A. Antunes. 2019. The impact of mixed dentition malocclusion on the oral health-related quality of life for children and their families: a case-control study. The fournal of Clinical Pediatric Dentistry 43(3):211-217. DOI: https://doi.org/10.17796/10534625-43.3.12

Pithon, M. M., C. C. Nascimento, G. C. G. Barbosa, e R. S. Coqueiro. 2014. Do dental esthetics have any influence on finding a job? American fournal of Orthodontics and Dentofacial Orthopedics 146(4):423429. DOI: https://doi.org/10.1016/j.ajodo.2014.07.001

Ravaghi, V., S. R., Baker, P. E. Benson, Z. Marshman, e A. Morris. 2019. Socioeconomic variation in the association between malocclusion and oral health related quality of life. Community Dental Health 36(1):17-21. DOI: https://doi.org/10.1922/CDH_4388Ravaghi05

Sfreddo, C. S., C. H. Moreira, B. Nicolau, e F. R. Ortiz. 2019. Socioeconomic inequalities in oralhealth-related quality of life: a cohort study. Quality of Life Research 28(9):2491-2500. DOI: https:// doi.org/10.1007/s11136-019-02229-2

Silva, L. F. G., E. B. A. F. Thomaz, H. V. Freitas, A. L. P. Pereira, C. C. C. Ribeiro, e C. M. C. Alves. 2016. Impact of malocclusion on the quality of life of Brazilian adolescents: a population-based study. Plos One 11(9):e0162715. DOI: https://doi.org/10.1371/journal.pone.0162715

Silva, S. S. C., F. A. R. Pontes, T. M. dos Santos, J. B. Maluschke, L. S. A. Mendes, D. C. Reis, e S. D. B. Silva. 2010. Rotinas familiares de ribeirinhos amazônicos: uma possibilidade de investigação. Psicologia: Teoria e Pesquisa 26(2):341-350. DOI: https://doi.org/10.1590/S0102-37722010000200016

Sun, L., H. M. Wong, e C. P. J. McGrath. 2017a. Relationship between severity of malocclusion and oral health related quality of life: A systematic review and meta-análise. Oral Health \& Preventive Dentistry 15(6):503-517. DOI: https://doi.org/10.3290/j.ohpd.a38994 
Sun, L., H. M. Wong, e C. P. J. Mcgrath. 2017b. The factors that influence the oral health-related quality of life in 12-year-old children: a baseline study of a longitudinal research. Health and Quality of Life Outcomes 15(1):155. DOI: https://doi.org/10.1186/s12955-017-0729-2

World Health Organization (WHO). 2013. Oral Health Surveys - basic methods. 5. ed. Geneva: World Health Organization. 